\title{
GUARDING THE MYSTERY AND MAJESTY OF GOD: REFLECTIONS ON THE HERMENEUTICAL IMPLICATIONS OF THE SECOND COMMANDMENT
}

\author{
Louis Jonker \\ Old and New Testament \\ Stellenbosch University
}

\begin{abstract}
The early post-exilic period in Israel's history saw a radical reinterpretation of Yahweh's presence among his people. This re-orientation was prompted by the significantly changed socio-religious conditions during the Persian era. Yahwism had to be defined in the absence of the luxurious sanctuary of the monarchic era, as well as in the context of a diversity of religions. Within this context the radical shift which is witnessed in the second commandment took place. A movement away from cult images to the strong prohibition of images (aniconism) was concluded. This movement is a reflection of the hermeneutical altercation on the mystery and majesty of God. The present paper investigates the hermeneutical implications of the second commandment for reflecting on human dignity in an African context. An overview will be provided of the history of research on the second commandment and the religious-historical circumstances that prompted it. Thereafter, the results of the overview will be brought into interaction with one particular Africentric interpretation of the Second Commandment.
\end{abstract}

Key Words: Second Commandment, Aniconism, Post-exilic Period, Hermeneutics, Afrocentric Interpretation

\section{Introduction}

"Thou shalt not make thee any graven image, or any likeness of any thing that is in heaven above, or that is in the earth beneath, or that is in the waters beneath the earth." This is how the old King James Version of Deuteronomy 5:8 translates the second commandment. One might think that it is relatively easy to speak about this commandment in a Reformed context. The Protestant Reformation, and particularly the Reformed version of the Reformation, took this commandment very seriously. Reformed architecture and interior decoration have, for example, been strongly influenced by a particular understanding of this commandment. Anti-iconism, and even iconoclasm, have been pursued strongly in the Reformed tradition (until fairly recently, at least!)

As a Reformed theologian and biblical scholar one might therefore be tempted to be complacent about this commandment to the extent that further reflection on it is deemed unnecessary! However, I would like to contend that the implications of this commandment stretch much further than church architecture and interior decoration. Although it would be possible to show how the interpretation of this commandment impacts deeply on our theological understanding, I leave this task to better equipped colleagues to fulfil. However, I would like to reflect in this contribution on what the implications of this commandment might be for our hermeneutical reflection on human dignity in an African context today. 
Implicit in this paper will also be the belief that our biblical hermeneutical inclination (which is profoundly influenced by the second commandment) is closely related to how we view human beings as agents of interpretation. I will show some implications in that direction in the last part of my paper. But, an overview of the history of research on this commandment will be provided first.

\section{History of Research on the Second Commandment}

Two aspects are commonly accepted in biblical scholarship today with reference to the second commandment. Firstly, it is commonly held that the commandment is probably a later insertion into the decalogue in Deuteronomy 5:8 (following the convictions expressed in Deut. 4). ${ }^{1}$ Early commentators have already indicated that the continuation in verse 9 cannot relate to verse 8 (which speaks of 'a carved image' - in the NKJV) because the command continues with a plural referent in verse 9, "you shall not bow down to them nor serve them". It is normally indicated that the first commandment, verse 7, probably continued in an earlier version into verse 9, which would make more logical sense, "You shall have no other gods before Me. ... (Y)ou shall not bow down to them nor serve them." The consensus among scholars is that the insertion of "You shall not make for yourself a carved image - any likeness of anything that is in heaven above, or that is in the earth beneath, or that is in the water under the earth" was made by the same hands who wrote Deuteronomy 4:15-40, a section concentrating on idolatry and containing similar phraseology than in the second commandment.

A second point of consensus is that the Exodus text (in 20:4) is a later version modelled after the Deuteronomic example. The only difference between Deuteronomy 5:8 and Exodus 20:4 is namely that the copula we- was added to the expression kol-temunah (normally translated with 'any likeness'). Although Hossfeld ${ }^{2}$ saw in this addition in Exodus 20:4 an attempt to make two different concepts out of 'carved image' and 'likeness', Köckert ${ }^{3}$ differs. He sees the copula as an explicative waw, which would mean that there is no content difference between the two versions.

Some other questions are debated more seriously, however. The first of these is the question: What is actually forbidden by the Second Commandment: Yahweh images, or idol images. The second issue flows from the first and concerns the religious-historical development in Israel in terms of iconism. A few remarks on each of these issues will now follow.

What is forbidden by the Second Commandment? Köckert is convinced that the commandment refers to cult images specifically. ${ }^{4}$ According to him the Hebrew concept used here, pesel, is never used merely as an indication of a work of art. It rather always refers to images which had a cultic function in the sanctuary or in private living spheres. Furthermore: Is this commandment a continuation of the first (vs. 7) where it is stated "You shall have no other gods before Me"? If so, the 'carved image' and 'likeness' of verse 8 would be a reference to idol images used for cultic purposes. However, Köckert again

\footnotetext{
See W Zimmerli (1969) "Das zweite Gebot", in W Zimmerli, Gottes Offenbarung. Gesammelte Aufsätze. Zweite Auflage. (TB 19), 234-248.

2 F-L Hossfeld (1982) Der Dekalog. Seine späten Fassungen, die originale Komposition und seine Vorstufen. (OBO 45), 21-26. See also F-L Hossfeld (1989) "Du sollst dir kein Bild machen! Die Funktion des alttestamentlichen Bilderverbots", Trierer Theologische Zeitschrift 98/2, 81-94.

3 M Köckert (2009), "Vom Kultbild Jahwes zum Bilderverbot. Oder: Vom Nutzen der Religionsgeschichte für die Theologie", ZThK 106, 377.

4 Köckert, "Vom Kultbild Jahwes zum Bilderverbot", 376-7.
} 
points to the singular form of the words pesel and temunah in verse 8 - the same grammatical phenomenon that prompted earlier scholars to assume that verse 8 was a later insertion at this point. According to him, the continuation of the plural forms from verse 7 to verse 9 shows that verses 9-10 are still dealing with the 'other gods' of verse 7, but that verse 8 surely intended something different. He states: "Wer das Bilderverbot von V.8 nachträglich eingeschoben hat, hatte offensichtlich etwas anderes im Sinn als lediglich eine Wiederholung des Verbots, das er im Zusammenhang von V.7.9 vorfand. Nachdem das Fremdgötterverbot alle Gottheiten ausser Jahwe ausgeschlossen hat, kann das Bilderverbot im Sinngefälle des Textes nur noch ein Kultbild für Jahwe meinen." ${ }^{5}$ Köckert's logic is clear: if the existence of other gods is vehemently denied in the first commandment, it would not make sense to forbid the making of images of these non-existing gods. One may therefore conclude with him that the commandment is a prohibition of cult images of Yahweh.

This, however, brings us then to another hotly debated issue namely: If cult images of Yahweh are forbidden, should we then accept that there was a phase in the religious history of Yahwism when such images were indeed present in the cult?

The classic position in this debate is represented by Tryggve Mettinger in his publication No Graven Image? Israelite Aniconism in Its Ancient Near Eastern Context of 1995. According to his investigations (particularly considering the role of empty spaces and masseboth in the cult of Israel) he comes to the conclusion that "Ancient Israel ... attests a form of West Semitic aniconism" and is in that respect not unique. He defines 'aniconism' as follows: "The term ... will be used to refer to cults where there is no iconic representation of the deity (anthropomorphic or theriomorphic) serving as the dominant or central cultic symbol." On account of this definition Mettinger then concludes: "First, Israelite aniconism is as old as Israel itself and not a later innovation. The express prohibition of images is just the logical conclusion of a very long development. Second, Israelite aniconism as such is not the result of theological reflection. Instead, it must be seen as an inherited convention of religious expression which only later formed the basis for theological reflection. Various attempts ... to explain aniconism as deriving from specific Israelite beliefs are to be considered disproven. Third, this de facto aniconism does not constitute one of Israel's differentia specifica." "Mettinger continues, however, to show that there was a "development from West Semitic aniconism to Israelite iconoclasm". In his description of this move he makes the distinction between de facto aniconism and programmatic aniconism. Texts such as the Second Commandment in Deuteronomy 5 and Exodus 20, as well as several others, testify to this development according to Mettinger. $\mathrm{He}$ continues: "The formulation of an express veto on images is certainly closely linked with the 'Yhwh alone movement', as has been shown particularly by Dohmen (1985). ... We may ... say that in Israel aniconism developed to its extreme: a programmatic anti-iconic attitude. Among ancient Semitic peoples there is hardly anything of similar dimensions. Whether or not this is due to the vicissitudes of archaeological discovery, we do not know of any express veto on images among other Semitic peoples of the ancient world. So it could be said with some justification that the express veto on images belongs to Israel's

Köckert, "Vom Kultbild Jahwes zum Bilderverbot", 377-378.

6 TND Mettinger (1995) No Graven Image? Israelite Aniconism it Its Ancient Near Eastern Context. CB 42. (Stockholm: Almqvist \& Wiksell International), 195.

7 TND Mettinger (1997), "Israelite Aniconism: Developments and Origins", in K van der Toorn (ed.) The Image and the Book. Iconic Cults, Aniconism, and the Rise of Book Religion in Israel and the Ancient Near East. (Leuven: Peeters), 174.

$8 \quad$ Mettinger, No Graven Image? 195. 
differentia specifica. In saying this, however, we should not forget that there is a later development of the same type in early Islam ... There are also certain archaeological traces of iconoclasm among the Nabateans..."

Although some reviewers of Mettinger's book, such as Loretz ${ }^{10}$ and Uehlinger, ${ }^{11}$ have already questioned certain aspects of his study, as well as his conclusions, it is particularly the recent studies by Köckert ${ }^{12}$ that have formulated an alternative position on the question whether the Yahweh cult was iconic, and on how the prohibition on images fits into that religio-historical picture. Köckert ${ }^{13}$ starts his argument by criticizing Mettinger's artificial distinction between anthropomorphic cult images and aniconic masseboth: "Anikonische Repräsentationen der Gottheit und anthropomorphe Kultbilder unterscheiden sich ... keineswegs hinsichtlich der Präsenz der Gottheit. .... Eine schroffe Alternative zwischen anikonischem Mazzebenkult und anthropomorphen Kultbildern wird den historischen Gegebenheiten offensichtlich nicht gerecht." ${ }^{14}$ In this point Köckert agrees with Uehlinger's criticism against Mettinger's view when he says: "Text und archäologische Befunde zeigen, dass die Grenze zwischen Kultstatue, Stele und Massebe offenbar weder randscharf noch absolut war." ${ }^{\prime 15}$ The non-acceptance of Mettinger's distinction, as well as his interpretation of the Second Commandment in Deuteronomy 5:8 (as we have seen above), then lead Köckert to assume that there must have been Yahweh cult images in the pre-exilic era. With reference to Bethel and Samaria (that is, in the Northern Kingdom), Köckert has little doubt that there must have been Yahweh images. He sees the calf images that were put up in Bethel (and Dan) by Jeroboam (as attested in 1 Kgs. 12) as Yahweh cult images. On account of the Sargon II prism from Nimrud he also assumes that the cult images that were taken as booty by the Assyrian king were not images of foreign gods, but rather Yahweh cult images. However, Köckert is careful not to transfer the finds in Bethel and Samaria directly onto Judah and the temple in Jerusalem as it is done in numerous accounts by Hellenistic-Roman authors (such as Tacitus, Strabon, Livius, Hekataios and Josephus) who attested to the Jews believing in a non-representable God, and the Jerusalem temple which consisted of empty rooms! Köckert is also not so convinced by authors (such as Herbert Niehr ${ }^{16}$ and Christoph Uehlinger ${ }^{17}$ ) who refer to some biblical texts to conclude that there must have been Yahweh cult images. The texts referred to by these authors can, according to Köckert, also be interpreted metaphorically. ${ }^{18}$ Moreover, we do not have any

\footnotetext{
Mettinger, No Graven Image? 196.

10 O Loretz (1995) "Semitischer Anikonismus und biblisches Bilderverbot. Review article on T Mettinger, No Graven Image," UF 26, 209-223.

11 C Uehlinger (1996) "Israelite Aniconism in Context," Bib 77, 540-549.

12 Apart from his "Vom Kultbild Jahwes zum Bilderverbot" mentioned above, also see M Köckert (2007) Die Zehn Gebote (Wissen: Beck).

In Köckert, "Vom Kultbild Jahwes zum Bilderverbot".

14 Köckert, "Vom Kultbild Jahwes zum Bilderverbot", 375.

Uehlinger, "Israelite Aniconism in Context", 544.

16 See H Niehr (2003) "Götterbilder und Bilderverbot", in M Oeming \& K Schmid (eds.) Der eine Gott und die Götter. Polytheismus und Monotheismus im antiken Israel (AThANT 82; Zürich: Theologischer Verlag), 227247. See also his earlier publication H Niehr (1997), "In Search of Yahweh's Cult Statue in the First Temple", in $\mathrm{K}$ van der Toorn (ed.) The Image and the Book, 73-96.

17 Apart from Uehlinger's "Israelite Aniconism in Context", also see C Uehlinger, "Anthropomorphic Cult Statuary in Iron Age Palestine and the Search for Yahweh's Cult Images", in K van der Toorn (ed.) The Image and the Book, 97-156.

18 Köckert finds support for this view in F-L Hossfeld (2003) "Das Werden des alttestamentlichen Bilderverbotes im Kontext von Archäologie, Rechtsentwicklung und Prophetie", in B Janowski \& N Zchomelidse (eds.) Die Sichtbarkeit des Unsichtbaren. Zur Korrelation von Text und Bild im Wirkungskreis der Bibel. (Stuttgart: Deutsche Bibelgesellschaft), 11-22; C Frevel (2003) "Du sollst dir kein Bildnis machen!
} 
archaeological finds - at least until now - that can unequivocally prove to us that there were Yahweh cult images in Jerusalem and Judah.

However, Köckert is of the opinion that biblical texts as sources of questioning on this issue have not been exhausted yet. He therefore spends a significant part of his study on the interpretation of the sermon in Deuteronomy 4 in which (as we have seen above) special attention is given to the prohibition of images. Köckert is convinced that the motivation of the prohibition on images, namely the fact that Yahweh appeared in a theophany at Horeb, but that the people could not see his temunah (his 'form', according to NKJV), indicates that reference is made here to cult images of Yahweh: "Der Gedankengang ist ganz klar. Weil das Bilderverbot (V.16) mit der Art der Theophanie Jahwes begründet wird (V.12.15), kann es sich nur um das Verbot eines Jahwe-Bildes handeln. .... Weil das Verbot im Ursprungsereignis Israels vor seinem Gott am Horeb verankert wird, muss es sich um eine Kultstatue im offiziellen Kult handeln." ${ }^{\prime 19} \mathrm{He}$ also points out that this Deuteronomistic section in Deuteronomy indicates that the making of a cult image of Yahweh leads to punishment. In vss. 27-28 it is stated (in the NKJV): "And the Lord will scatter you among the peoples, and you will be left few in number among the nations where the Lord will drive you. And there you will serve gods, the work of men's hands, wood and stone, which neither see nor hear nor eat nor smell." This is clearly a back-reference to the Exile by those Deuteronomists who added Deuteronomy 4 to the corpus of deuteronomic legislation: "Dtn 4 überblickt die gesamte kanonische Geschichte Israels von der Herausführung aus Ägypten bis zum Exil 587, ja bis zur Rückkehr zu Jahwe. Als Generalschlüssel für diese Geschichte wird allein das Bilderverbot gebraucht. Dtn 4 blickt auf das Ende der Geschichte im Land zurück und erklärt es nicht mit Verstössen gegen das Fremdgötterverbot, sondern gegen das Bilderverbot. Das ist im Alten Testament einzigartig. "20 Deuteronomy 4 therefore states, according to Köckert's interpretation, that Israel went into Exile because they have made a Yahweh cult image, without them having seen a 'form' of Yahweh in the theophany at Horeb. ${ }^{21}$ The prohibition in Deuteronomy 4:15-19 therefore excludes the making of any image of Yahweh: "Take careful heed to yourselves, for you saw no form when the Lord spoke to you at Horeb out of the midst of the fire, lest you act corruptly and make for yourselves a carved image in the form of any figure: the likeness of male or female, the likeness of any animal that is on the earth or the likeness of any winged bird that flies in the air, the likeness of anything that creeps on the ground or the likeness of any fish that is in the water beneath the earth." (NKJV) Köckert concludes: "Damit schliesst das Verbot alle nur denkbaren Weisen der kultischen Repräsentation aus, auch nichtfigurative. Es bezieht sich also in der Tat auf theriomorphe und anthropomorphe Kultstatuen, auf anikonische Mazzeben und Ascheren, aber genauso auch auf leere Throne. In der Konsequenz dieser Radikalisierung liegt der ausdrückliche Verzicht auf jede symbolische

- Und wenn doch? Ueberlegungen zur Kultbildlosigkeit der Religion Israels”, in B Janowski \&

N Zchomelidse (eds.) Die Sichtbarkeit des Unsichtbaren, 23-48; F Hartenstein (2008) Das Angesicht JHWHs (FAT 55; Tübingen: Mohr-Siebeck)

19 Köckert, "Vom Kultbild Jahwes zum Bilderverbot", 387.

20 Köckert, "Vom Kultbild Jahwes zum Bilderverbot", 387.

21 One could, of course, argue that Köckert's strategy of interpreting Deut. 4 is nothing different from the strategy used by Niehr and Uehlinger in the interpretation of other Old Testament texts. One could equally criticize Köckert's interpretation by indicating that this text could also be seen as metaphorical. In conclusion Köckert does not employ such a different argumentation than the other scholars. However, his argument from Deut. 4 presents a critical cross-check of those other interpretations, which could be useful in this scholarly endeavour. 
Repräsentanz Jahwes im Heiligtum. ${ }^{, 22}$ In this statement Köckert takes an alternative view than Mettinger's.

This prohibition, together with its motivation, represents a completely new argumentation. The fact that this very radical prohibition of all Yahweh images was even inserted into the first commandment in Deuteronomy 5 (in verse 8) underlines that some drastic event must have triggered this development. As Köckert puts it, it must have been some development which was impossible to handle only with the idol prohibition in Deuteronomy 5:7,9.

Köckert then continues to relate this complete prohibition of Yahweh images to the exilic situation and particularly to the building of the Second Temple. With the Babylonian destruction the Yahweh cult image - which we may assume existed in the First Temple - as well as the Ark of the Covenant and the cherubim throne which served as pedestal for the Yahweh image, were destroyed. With the planning of the rebuilding of the Temple in the early post-exilic phase the question arose how Yahweh's presence should be expressed in the cult. However, since the Exile resulted into a break-off with the past cultic traditions, different views arose on this issue, as can be seen in the different biblical witnesses. Not only the exilic contribution from Deuteronomy 4, but also the post-exilic prophetic voice of Zechariah and the priestly writing contributed to this discussion. According to Köckert, the position of Deuteronomy 4 gained the upper hand as time went by. This happened on account of the deliberate theological interpretation of Yahweh's role in the Exile and beyond and against the background of Ancient Near Eastern religious ideas. Deuteronomy 4 wanted to reflect on Yahweh's punishment of his people through the Exile, but also on the appropriateness of Israel's understanding of Yahweh's presence among them. Köckert points to certain analogies in the Shamash cult in Sippar of Babylonia. The view was commonly held there (as also elsewhere in the Ancient Near East) that an image can only be a cult image if the deity involved him-/herself in the manufacturing of the image. If the god does not show him-/herself, no image can be made of this god. When the deity Shamash, for example, burnt in anger against the city of Sippar, he hid himself from the inhabitants so that nobody could make any image of the deity. Deuteronomy 4, when indicating that Yahweh did not show his temunah to Israel, similarly suggests that Israel's God hid himself from his people because of their transgression in the monarchic cult. The Exile was therefore seen as a sign of Yahweh's absence and concealment. However, Deuteronomy 4 departs from the Shamash theology in one remarkable respect: Yahweh does not remain hidden. Although his 'form' cannot be seen (and should not be seen) his voice can be heard in the Ten Commandments. Köckert puts it as follows: "Auf diese Weise verschränkt Dtn 4 die Erfahrung der zornigen Verbergung Jahwes mit seiner erneuten gnädigen Zuwendung. Die Zuwendung Jahwes nach dem Gottesgericht des Exils enthält jedoch für immer die Erfahrung seiner Abwesenheit in sich. Das Bilderverbot trägt dieser neuen Gotteserfahrung Rechnung und sichert sie. Jahwe bleibt in seiner Zuwendung verborgen: Er lässt nichts von sich sehen, sonder allein hören ... Deshalb hat keiner seine Gestalt gesehen. An die Stelle des Kultbildes tritt die Tora mit den Zehn Worten und dem Bilderverbot als Hauptgebote." 23 Or, to put it in the words of my title: In the Second Commandment the majesty and mystery of Yahweh is guarded. In this commandment account is given for Yahweh's absence and simultaneous presence in the life of His people.

The main difference between Mettinger's classical position and Köckert's alternative position lies in the way in which the change to a prohibition of all images is described by

Köckert, "Vom Kultbild Jahwes zum Bilderverbot”, 389.

23 Köckert, "Vom Kultbild Jahwes zum Bilderverbot", 404. 
these scholars. Whereas Mettinger sees this change as the natural result of changed sociopolitical circumstances after the Exile, Köckert emphasises the deliberate theological interpretation of Yahweh's absence and presence in the early Second Temple period: "In der klassischen Position erscheint das Bilderverbot lediglich als eine Antwort auf die Herausforderungen einer neuen Zeit ... In der Alternativposition trägt das Bilderverbot ausdrücklich der nach dem Untergang von Tempel, König und Staat im Zorngericht erfahrenen Verborgenheit Gottes Rechnung." 24

The Second Commandment is therefore not merely a prohibition to make any physical images of God. It is rather a very deep theological reflection on the mysteriousness of God. This commandment reminds Israel in the phase of reconstructing the temple and their cult, that Yahweh cannot be claimed for the aspirations of the people. He remains hidden, but simultaneously lets his voice be heard by revealing Himself through his Torah.

\section{Implications for Reflecting on Human Dignity in an African Context}

Let me now try to show some implications of this understanding of the Second Commandment for our reflection on human dignity - particularly in an African context.

We have seen above that the Second Commandment indicates that Yahweh's 'form' is concealed, but it also reminds people of faith that Yahweh's voice can be heard in the Torah. The Second Temple community reminded themselves of this truth by re-imagining the Ark of the Covenant with two tables of the Torah in it, instead of being the pedestal on which Yahweh's image was supported. Mystery and revelation belong together.

Any reading of Torah (in the broadest sense of the word) that would isolate any of these aspects would be in danger of transgressing the Second Commandment. In practical terms, any interpretation of Scripture that would lead to a denial that God's Word speaks to every generation in new circumstances, would not take seriously that the Second Commandment reminds us that God's voice can be heard. And equally, any interpretation that would lead to statements about God which claim finality and certainty, would forget that the Second Commandment reminds us that God's image cannot (and may not) be seen. The Second Commandment requires and desires a hermeneutic that can live with mystery, but also simultaneously with contextualized revelation.

What would this imply for our reflection on human dignity in an African context? In another contribution in this volume, Holter indicates that the Second Commandment "has not received much attention from Old Testament scholars in Africa, at least not north of the Limpopo River. ... [T] he general impression is that this is a neglected field of research within the African guilds of Old Testament studies." ${ }^{, 25}$ It is therefore difficult to engage in conversation with existing African perspectives on the matter. One available publication can, however, serve as example of how an "Afrocentric mode of inquiry" would interpret the commandment, namely the study by Earl D Trent Jr titled "Breaking the Myths, Shattering the Shackles: Interpreting the Second Commandment". ${ }^{26}$ Trent, an AfricanAmerican, ${ }^{27}$ explains his approach as follows: "In the mode of recontextualization, this

Köckert, "Vom Kultbild Jahwes zum Bilderverbot", 406.

25 He mentions the exception of one dissertation by Abel L Ndjerareou from Chad who completed a PhD thesis in the United States on the topic The Theological Basis for the Prohibition of Idolatory: An Exegetical and Theological Study of the Second Commandment (1995). Since this work is unpublished I could not gain access to it.

26 ED Trent Jr (2001) "Breaking the Myths, Shattering the Shackles: Interpreting the Second Commandment," Journal of Religious Thought 56-57, 63-73.

27 Trent is pastor of the Florida Avenue Baptist Church in Washington DC. 
paper examines the second commandment in the Decalogue. It is my contention that this Afrocentric mode of inquiry is essential in arriving at an interpretation that addresses what heretofore have been inadequate explanations for the origins of Israel's aniconic tradition and the importance of the second commandment." 28

In his overview of scholarship on the Second Commandment Trent discusses the work of Ronald S Hendel ${ }^{29}$ who takes his cue from the work of Norman Gottwald to provide a sociological interpretation of the Second Commandment. According to Hendel the prohibition of divine images reflects the early Israelite bias against the institution and ideology of kingship. The commandment should therefore be seen as a polemic against all those cultures which saw the king as the son of the deity, and against similar trends in the kingship of early Israel. Trent is of the opinion that Hendel is on the right track with his sociological interpretation, but his interpretation is flawed on the following point: "Hendel centers his analysis on a comparison of early Israelite religion with Canaanite religion and never takes seriously the African-Egyptian social world that is clearly part of Israel's heritage. Hendel, like most other scholars of a Eurocentric perspective, pushes Egypt and its influences to the periphery... There is little acknowledgment or reference to the Egyptian religion and to the contrast between it and Israel's religion. It is my contention that an Afrocentric recontextualization gives a much more cogent explanation to this aniconic tradition.",30

Trent continues to indicate that "we must take seriously the description that Israel gives of itself in the book of Exodus. In broad terms, the Israelites were slaves in Egypt for a protracted period of time and eventually were freed from this bondage." 31 He makes use of a study by John Baines to indicate that there was a huge divide in Egypt between the ruling and administrative class, and the rest of the population. The Israelites, being slaves, belonged to "the lowest rungs of Egyptian society" that were not favoured by history: "History is not told from the viewpoint of people on the bottom rungs of society. The privilege of literacy elevates one immediately to an elite status but does not have to affect one's collective memory." 32 According to Trent the collective memory of Israel in Egypt remained vibrant in their formulation of the Second Commandment: "It was not hard for the Hebrews to see the relationship between their sweat and labor and the multitude of temples and deities that were worshipped and represented through the various images. It was a massive industry that thrived on the backs of those slaves. Slave labor contributed to the massive public works projects. Egypt's local economy was supported by the imagemaking industry that was related to the temple and its religion." 33 He therefore relates the Second Commandment to the deep resentment among the Egyptian under class against the upper class: "What became written into Hebrew laws and code of conduct was more than a personal resentment. It was a rejection of the Israelites' former life. It was a rejection of an economic system they understood far too well. The temple and idol industry was anathema to them, and they refused to participate in it or compromise with it." 34 However, Trent

\footnotetext{
Trent, "Breaking the Myths", 63.

See RS Hendel (1988) "The Social Origins of the Aniconic Tradition in Early Israel," CBQ 50, 365-382.

Trent, "Breaking the Myths", 65.

Trent, "Breaking the Myths", 65.

Trent, "Breaking the Myths", 67.

Trent, "Breaking the Myths", 68. Trent then refers to the book of Acts to support his argument. I find this intertextuality that Trent sees between the position of the Israelites and the position of the early Christians in Asia Minor unsatisfactory, not only because of the temporal and spatial differences between these two contexts, but particularly also because of the cultural and religious differences between the mentioned contexts.

34 Trent, "Breaking the Myths", 68-69.
} 
indicates that the Second Commandment is also a positive assertion: "It is an economic manifesto of liberation. Although it does not describe a complete economic theory, it does declare that Israel will participate in other ways of life, worship, work, and trust that will be blessed by God and prosper." 35 Unfortunately, according to Trent, this socio-economic mode of interpretation is often not given expression in studies on the Second Commandment: "Ironically, this manifesto has been overlaid with gilded theology and has lost its effect over the centuries. The prohibition against idol making soon became doctrinal and theological. The Promised Land was not an abstract hope and neither was the economic intention of the Israelites. ... To view the second commandment as an economic manifesto is to attack one of the most enduring myths regarding religion, namely that good religion somehow exists apart from the reality of economic systems and conditions." 36

How should one assess this Afrocentric and socio-economic interpretation by Trent? And how can one bring his interpretation into interaction with the interpretation of Köckert (being representative of an Eurocentric voice), described in the previous section? It should be noted that both Köckert and Trent take their respective points of departure in sociological conditions (the socio-religious conditions of the Persian era, in the case of Köckert, and the socio-economic conditions of the slavery in Egypt, in the case of Trent). The main (and, in my opinion, very important) difference between their presuppositions is that Trent works with the sociological conditions reflected in the Hebrew Bible narrative world, while Köckert reflects the sociological circumstances during the time of origin of this literature. Trent does not give any indication of how the socio-economic collective memory of the slavery in Egypt would have contributed to sense-making in the post-exilic Persian Empire, which is most probably the time of origin of this commandment. His interpretation is strongly determined by his interest in bringing Africa into his hermeneutic, as put in his introduction: "Africentrism forces a rethinking of Western bias toward having a European worldview as the norm for theological reflection and biblical interpretation. ${ }^{37}$ It is rather the socio-economic position of modern readers of the Second Commandment that determines Trent's interpretation, and he finds resonance of this position in the narrative world of the biblical text.

Köckert on the other hand, focuses very strongly on the meaning of the Second Commandment in post-exilic Israel, without reflecting too much on how his European reading position influences his understanding. Although he relates his interpretation to our understanding of the theological task today, his intention is not to provide an interpretation of the commandment for a specific contemporary context.

Again, how should one evaluate these different approaches? Although my own scholarly inclination and biographical profile would rather lead me to express preference for an interpretation such as Köckert's which takes seriously the conditions of origin of the Biblical literature (rather than merely the situation reflected in the literary world of the texts), I would like to be challenged by the result of exactly such an interpretation. Above I concluded from Köckert's approach that the Second Commandment requires and desires a hermeneutic that can live with mystery, but also with contextualized revelation. Let me repeat that conclusion: Any reading of Torah (in the broadest sense of the word) that would isolate any of these aspects would be in danger of transgressing the Second Commandment. In practical terms, any interpretation of Scripture that would lead to a denial that God's Word speaks to every generation in new circumstances, would not take seriously that the

\footnotetext{
Trent, "Breaking the Myths", 69.

Trent, "Breaking the Myths", 69.

Trent, "Breaking the Myths", 63.
} 
Second Commandment reminds us that God's voice can be heard. And equally, any interpretation that would lead to statements about God which claim finality and certainty, would forget that the Second Commandment reminds us that God's image cannot (and may not) be seen.

In light of this conclusion I would like to assess these two interpretations of the Second Commandment. It seems that Trent's Afrocentric interpretation would emphasize that "God's voice can be heard", that is, that the biblical interpreter should insist that the commandment finds application in some concrete, contemporary reality. His interpretation touches the lives of many African people who still live in poverty and oppression, and who want to give expression to their resistance against regimes that keep up these systems of oppression. His interpretation would also open vast possibilities of applying the Second Commandment in any reflection on human dignity. However, Trent's interpretation does not attend in any way to the mysteriousness of God. His interpretation remains on the level of socio-economic appropriation in which God is fully claimed to be on the side of those interpreting the text for their (African) contexts.

In the case of Köckert's interpretation, it seems that he emphasizes the mystery of God, symbolized by the aniconic claim of the Second Commandment. He does, however, not reflect on what "the voice of God" would mean in a concrete, contemporary context. His interpretation would therefore be disappointing to those on (for example) the African continent who long for liberation from their socio-political and socio-economic plight, and would also remain less useful in any discussion on human dignity.

The fact that the Second Commandment indicates that no image of God may be made, but simultaneously that God's voice can be heard in the Torah, shows that these aspects are two sides of the same coin. Any reflection on human dignity should take place within the field of creative tension between the mystery and majesty of God, and the revelation of God in concrete human conditions.

\section{Conclusion}

In this paper my main focus was to investigate the history of research on the Second Commandment. I found the alternative position of Köckert illuminating in its emphasis of the fact that this commandment is not a mere reflection of a natural development in the religion history of Ancient Israel, but rather the product of deep theological thinking in the aftermath of the Exile. The Second Commandment guards the majesty and mystery of the God of Israel, and it urges believers through the ages to give account for the majesty and mystery of God in their own context.

However, I also let Köckert's interpretation, as well as my affiliation with his interpretation, be challenged by an Afrocentric appropriation of the Second Commandment. One may conclude with the hermeneutical observation that the way forward does not lie in an either-or situation: either the one (Eurocentric), or the other (Afrocentric) interpretation should be accepted. A responsible hermeneutical approach would rather be to bring these (often extreme) interpretations into dialogue with one another. ${ }^{38}$ The inter-subjectivity of such a dialogue may help us to guard the majesty and mystery of God, as well as to give expression to the fact that God reveals Himself through his 'voice' in our deliberations on human dignity.

38 See the following volume in which numerous interactions between African and European interpreters are documented: GO West \& JH de Wit (eds.) (2008) African and European Readers of the Bible in Dialogue. Leiden: Brill. 